\title{
MEDICINE
}

\section{LABOR COURSE AND CONDITION OF NEWBORNS IN WOMEN WITH PLACENTAL DYSFUNCTION DUE TO GESTATIONAL ENDOTHELIOPATHY}

\author{
${ }^{1}$ Prof., MD V. V. Lazurenko \\ ${ }^{2}$ Post-graduate student I. B. Borzenko \\ ${ }^{3}$ Post-graduate student $\boldsymbol{D}$. Yu. Tertyshnik \\ Ukraine, Kharkiv, Kharkiv National Medical University \\ ${ }^{1}$ Head of t Department of Obstetrics and Gynecology No. 2 \\ 2. ${ }^{3}$ Post-graduate student of the Department of Obstetrics and Gynecology No.2
}

DOI: https://doi.org/10.31435/rsglobal_ws/30092019/6704

\begin{abstract}
ARTICLE INFO
Received: 16 July 2019

Accepted: 10 September 2019

Published: 30 September 2019

KEYWORDS

gestational endotheliopathy, placental dysfunction.

ABSTRACT

The purpose of the study is to evaluate the effect of placental dysfunction caused by gestational endotheliopathy on the course of labor and the condition of the newborn. The first group consisted of 70 patients with placental dysfunction with gestational endotheliopathy confirmed by laboratory-instrumental findings in the first trimester of pregnancy. The control group included 30 pregnant women with physiological gestational course. PD secondary to GE leads to preterm birth, fetal distress, increases the percentage of caesarean section, contributes to the delay of fetal growth and birth weight, poor infant status and perinatal complications.
\end{abstract}

Citation: V. V. Lazurenko, I. B. Borzenko, D. Yu. Tertyshnik. (2019) Labor Course and Condition of Newborns in Women with Placental Dysfunction Due to Gestational Endotheliopathy. World Science. 9(49), Vol.2. doi: 10.31435/rsglobal_ws/30092019/6704

Copyright: (C) 2019 V. V. Lazurenko, I. B. Borzenko, D. Yu. Tertyshnik. This is an open-access article distributed under the terms of the Creative Commons Attribution License (CC BY). The use, distribution or reproduction in other forums is permitted, provided the original author(s) or licensor are credited and that the original publication in this journal is cited, in accordance with accepted academic practice. No use, distribution or reproduction is permitted which does not comply with these terms.

Introduction. Placental dysfunction (PD) remains one of the urgent problems of obstetrics, occuring in $15-35 \%$ of women in physiological pregnancy and in $24-80 \%$ of women with obstetric and extragenital abnormalities, reaching $40 \%$ in the structure of complications of pregnancy with no tendency to decrease and is the basis of high level of perinatal morbidity and mortality, disorders of neuropsychic development and adaptation of children [3,5,7].

Despite the introduction of new methods of PD diagnosis and prevention into obstetric practice, a clear tendency to decrease its incidence is not observed, and this problem continues to be relevant in modern obstetrics. Defective placentation and, as a consequence, PD is the direct cause of what is called "major obstetric syndromes": preeclampsia, fetal growth retardation syndrome (FGR), preterm birth, premature rupture of the membranes, premature placental abruption $[8,10]$. PD should be considered as a clinical syndrome associated with morpho-functional changes in the placenta, due to disorders of compensatory and adaptive properties in the "mother-placenta-fetus" system [1,9]. PD is characterized by a complex of disorders of trophic, transport, endocrine and metabolic function of the placenta, which underlie the development of pathology of the fetus and newborn $[4,8]$. The nature and extent of the impact of different pathologies during pregnancy on the fetus is determined by various factors: gestation time, duration of exposure, condition of the feto-placental complex [1].

In recent years, the problem of gestational endotheliopathy (GE) - the violation of vasodilating, angioprotective, antiproliferative functions of emerging endothelium during pregnancy - is of great interest. As a result, the following occur: discoordination of vascular tone; activation of proliferative processes of 
the vascular wall; changes in the structure and number of endothelial cells; the property of the inner surface of the vascular wall adhesive properties $[2,6]$.

Studies of the role of GE in the development of perinatal pathology and methods of prevention of obstetric complications are very few, extremely controversial and contain different views on the problem. In view of the above, it is advisable to study the clinical and morphological, markers of vascular wall thrombogenicity and factors of regulation of adhesive substances of endothelial origin in gestational endotheliopathy. However, the focus of modern clinicians is on some measures in placental dysfunction that will improve the prognosis of gestation, the occurrence of PD, to develop a personalized strategy for optimal term and mode of delivery, and as a consequence, to prevent the development of obstetric and early neonatal disorders.

The purpose of the study is to reduce the incidence of perinatal complications in women with placental dysfunction based on a study of the effect of gestational endothelial disease on labor and neonatal status.

Materials and methods. The first (main) group consisted of 70 patients with placental dysfunction and gestational endotheliopathy confirmed by laboratory-instrumental findings (MAU greater than $5 \mathrm{mg}$ albumin / mmol creatinine and EDV less than 10\%) in the first trimester of pregnancy. Whereas the second (control) group comprised 30 pregnant women with physiological gestational course without placental dysfunction, with no endothelial dysfunction, whose clinical and laboratory parameters were the control ones for comparing the examination data of pregnant women with PD of the main group.

Given the different genesis of placental dysfunction, to clarify the contribution of risk factors to the development of this pathological condition, the main group was divided into 2 subgroups: subgroup A - 40 patients with PD and fetal growth retardation syndrome (FGR) and subgroup B - 30 pregnant women with PD and without FGR.

PD was detected according to the clinical course of pregnancy, the results of ultrasound and Doppler examination of pregnant women, the results of laboratory examination. FGR was diagnosed by a delay in fetometry indicators by 2 weeks and more from gestational term.

Statistical processing of the results was carried out using Statistica 6.0.

Results of the study. In all clinical groups of the prospective study, patients' ages ranged from 25 to 40 years, with an average of $31.2 \pm 4.3$ years in subgroup A, $30.8 \pm 4.6$ years in subgroup B of the main clinical group, and $29.7 \pm 3.9$ years in pregnant women with physiological gestational course.

The number of pregnant women who gave birth for the first and second time, as well as the number of first-time and second-time pregnant women in all PD subgroups was similar and did not have significant differences $(\mathrm{p}>0.05)$.

In the group of pregnant women with placental dysfunction, the prevalent number of subjects (77.1\%) gave birth for the first time, only 16 patients (22.9\%) gave birth again (without a significant difference between subgroups A and B). In the control group, a similar tendency was observed between women who gave birth for the first time, $73.3 \%$ and repeatedly, $26.7 \%$.

In pregnant women in the control group, all pregnancies ended in childbirth within 39 - 41 weeks (Table 1). Whereas, the number of preterm births up to $33+6$ days in pregnant women with manifested PD secondary to gestational endotheliopathy reached $17.5 \%$. Premature births in patients of subgroup A in the above pregnancy term occurred due to fetal distress in 5 cases $(12.5 \%)$ and in two $(5.0 \%)$ because of premature placental abruption.

Table 1. Labor term in women with placental dysfunction secondary to GE $(\mathrm{n}=100)$

\begin{tabular}{|c|c|c|c|c|}
\hline Labor term & $\begin{array}{l}\text { Subgroup A } \\
\quad(n=40)\end{array}$ & $\begin{array}{c}\text { Subgroup B } \\
(\mathbf{n}=\mathbf{3 0})\end{array}$ & $\begin{array}{c}\text { Control group, } \\
\mathbf{n}=\mathbf{3 0}\end{array}$ & Relative risk (RR) \\
\hline Up to $33+6$ days weeks & $7(\mathbf{1 7 . 5 )}$ & - & - & \\
\hline 34 - 36+6 days weeks & 13 (32.5) & $7(\mathbf{2 3 . 3})$ & - & $\begin{array}{l}\mathrm{RR}_{\mathrm{aB}} 1.39,95 \% \text { CI }[0.63 \\
-3.06], \mathrm{p}=0.41 .\end{array}$ \\
\hline $\begin{array}{l}\text { Total number of patients } \\
\text { with preterm birth }\end{array}$ & $20(50)$ & 7 (23.3) & - & $\begin{array}{l}\mathrm{RR}_{\text {ав }} 2.14,95 \% \text { CI [1.04 } \\
-4.40], \mathrm{p}=0.04 .\end{array}$ \\
\hline $37-41$ weeks & $20(\mathbf{5 0 . 0 )}$ & $23(\mathbf{7 6 . 7 )}$ & $30(\mathbf{1 0 0})$ & \\
\hline Cesarean section & $15(37.5 \%)$ & $5(16.7 \%)$ & $2(6.7 \%)$ & $\begin{array}{l}\mathrm{RR}_{\text {ав }} 2.25,95 \% \text { CI [0.92 } \\
-5.50], \mathrm{p}=0.08 . \\
\mathrm{RR}_{\text {ак }} 5.62,95 \% \text { CI [ } 1.39 \\
-22.75], \mathrm{p}=0.015 . \\
\mathrm{RR}_{\text {вк }} 2.50,95 \% \text { CI }[0.52 \\
-11.89], \mathrm{p}=0,25 . \\
\mathrm{RR}_{\text {aвк }} 4,29,95 \% \text { CI } \\
{[1.07-17.19], \mathrm{p}=0.04 .}\end{array}$ \\
\hline
\end{tabular}


Note - the comparison of groups by the frequency of the case was carried out using exact Fisher test (two-sided test).

During the period of 34-36 + 6 days of pregnancy, the births occurred in 13 patients with fetal growth retardation syndrome $(32.5 \%)$ and in 7 women $(23.3 \%)$ with pre-nosological form of placental dysfunction. However, the difference in this indicator between the clinical study groups was not significant (RR 1.39, 95\% CI [0.63 - 3.06], $\mathrm{p}=0.41)$. The causes of preterm birth in subgroup A were: premature rupture of fetal membranes in 8 cases $(20 \%)$ and acute fetal distress in $5(12.5 \%)$. In patients with pre-clinical PD, the causes of preterm delivery were: PRFM in 2 patients $(6.7 \%)$ and in $5(16.7 \%)$ acute fetal distress. By the total number of preterm births, we noted a significant increase in the indicated index in patients with FGR compared with the non-manifested form of PD (RR 2.14, 95\% CI [1.04 - 4.40], $p=0.04$ ).

It should also be noted that the number of cases of caesarean section (CS) reached 15 patients (37.5\%) in the subgroup of pregnant women with manifested PD and had a significant difference compared with pregnant women with physiological gestational course, RR 5.62, 95\% CI [1.39 - 22.75], p $=0.015$ (Table 1). According to the case index of the patient from group B, there was no reliable result either for women from the control group $(p=0.25)$ or for patients with FGR $(p=0.08)$. However, the total number of cases of caesarean section in pregnant women with placental dysfunction outweighed the same in women with physiological gestational course, RR 4.29, 95\% CI [1.07 - 17.19], $\mathrm{p}=0.04$.

Cases of acute fetal distress in childbirth were diagnosed in $45 \%$ of patients with clinically manifested placental dysfunction, and significantly more prevalent in the population of pregnant women with preclinical PD (13.3\%), RR 3.37, 95\% CI [1.27-8.94], $\mathrm{p}=0.014$. There were no cases of acute fetal distress in women with a physiological pregnancy.

Bleeding in labor was diagnosed in 3 pregnant women (7.5\%) from clinical subgroup A. In clinical subgroup B, the above complication was diagnosed only in 1 case $(3.3 \%)$, RR $2.25,95 \%$ CI [0.25-20.57], $\mathrm{p}=0.47$.

Afterbirth defect was determined in 8 cases $(20 \%)$ in patients with fetal growth retardation syndrome, in 3 women of subgroup B (10\%), RR 2.0, 95\% CI [0.58-6.91], p =0,27. The overall RR index for the presence of afterbirth defect between the clinical study group and women with physiological pregnancy was $4.29,95 \% \mathrm{CI}[0.57-32.01], \mathrm{p}=0.16$, and had no statistically significant difference.

The aforementioned premature rupture of the fetal membranes was registered in 14 pregnant women with FGR (35\%) and in 7 women with asymptomatic form of placental dysfunction $(23.3 \%)$, RR 1.50, 95\% CI [0.69-3.25], $\mathrm{p}=0.30$. Generalized indicator for the presence of PRFM between patients with PD secondary to gestational endotheliopathy and pregnant women from the control group was 3.00, 95\% CI [0.97-9.30], $\mathrm{p}=0.06$.

Assessment of cases of labor abnormalities (LA) showed a rather large number of these disorders in women whose pregnancy was complicated by placental dysfunction. 15 pregnant women with manifested PD (37.5\%) were found to have uterine inertia, mainly in the first period of labor, whereas the above mentioned abnormality was noted in 8 cases (26.7\%), RR 1.41, 95\% CI [0.69-2.88], $\mathrm{p}=0.35$. When comparing the number of LA cases between pregnant PD patients and controls (practically healthy women), we found a significant difference in outcomes, RS 3.29, 95\% CI [1.07-10.12], p = 0.04.

Pregnant women, who were involved in our prospective study, gave birth to 100 children (Table 2). Due to personification of the risk of development of perinatal pathology, we not only managed to avoid cases of antenatal mortality, but also to prevent intranatal and early neonatal losses in patients with placental dysfunction secondary to gestational pathology (constant monitoring of intrauterine scan, pregnancy, severe restrictions on the use of medicines). The ratio of boys to girls was approximately the same in all study groups. The growth rate of newborns among patients in clinical subgroup A was $47.3 \pm 2.4 \mathrm{~cm}$, on average, while in women with preclinical PD it was $48.9 \pm$ $1.8 \mathrm{~cm}$ (Table 2). We found no statistically significant difference in the sex and growth rates of newborns in patients with placental insufficiency and women with physiological pregnancy $(\mathrm{p}>0.05)$.

Table 2. Functional evaluation of newborns from pregnant women with placental insufficiency secondary to gestational endotheliopathy, $(n=100)$

\begin{tabular}{|l|c|c|c|}
\hline \multicolumn{1}{|c|}{ Labor term } & Subgroup A (n= 40) & Subgroup B (n= 30) & Control group, $\mathbf{n = 3 0}$ \\
\hline Height, cm & $47.3 \pm 2.4$ & $48.9 \pm 1.8$ & $50.14 \pm 0.8$ \\
\hline Weight, g & $2724.2 \pm 284.5^{*}$ & $3184.8 \pm 170.0$ & $3559.5 \pm 152.8$ \\
\hline $\begin{array}{l}\text { APGAR score during the } \\
1^{\text {st }} \text { min, points }\end{array}$ & $5.79 \pm 1.3^{*}$ & $6.82 \pm 0.7$ & $7.90 \pm 0.3$ \\
\hline $\begin{array}{l}\text { APGAR score during the } \\
5^{\text {th }} \text { min, points }\end{array}$ & $6.85 \pm 1.0^{*}$ & $7.75 \pm 0.7$ & $8.86 \pm 0.4$ \\
\hline
\end{tabular}


Note - the comparison of groups by the frequency of the case was carried out using exact Fisher test (two-sided test).

Children born from pregnant women with FGR, which seemed quite logical, had the weight within $2724.2 \pm 284.5 \mathrm{~g}$, which was significantly less $(\mathrm{p}<0.05)$ than the weight of newborns from women with uncomplicated pregnancy $(3559.5 \pm 152.8 \mathrm{~g})$. All newborns in the control group were born in a satisfactory condition, 26 infants $(86.7 \%)$ were born with an APGAR score of 8/9 points, 4 children (13.3\%) with a score of 7/9 points. Neonates born from pregnant patients from subgroup A had a significantly lower $(\mathrm{p}<0.05)$ APGAR score, both at $5.79 \pm 1.3$ points at the $1^{\text {st }}$ minute and 6.85 at the $5^{\text {th }}$ minute. \pm 1.0 points, relative to similar indicators of women in the control group. Whereas children born to patients with pre-nosological PD had a lower score on the assessment of the condition of the child at the $1^{\text {st }}$ and $5^{\text {th }}$ minutes compared to women who were physiologically pregnant, but the difference did not have statistical significance $(p>0,05)$.

Infants born to women in the control group were not diagnosed with CNS disorders. Perinatal disorders were diagnosed in 12 preterm infants $(30 \%)$ from pregnant women with FGR and in 3 infants (10\%) from women in clinical subgroup B who were also born prematurely, RR $3.0,95 \%$ CI [0.93- 9.70], $\mathrm{p}=0.07$ (Table 3).

Table 3. Assessment of neonatal disorders in pregnant women with placental insufficiency secondary to gestational endotheliopathy, $(\mathrm{n}=100)$

\begin{tabular}{|l|c|c|c|}
\hline \multicolumn{1}{|c|}{ Neonatal disorder } & Subgroup A (n= 40) & Subgroup B $(\mathbf{n}=\mathbf{3 0})$ & Control group, $\mathbf{n}=\mathbf{3 0}$ \\
\hline $\begin{array}{l}\text { Perinataal CNS disorders, } \\
(\mathrm{n} / \mathbf{\%})\end{array}$ & $12(\mathbf{3 0 . 0})$ & $3(\mathbf{1 0 . 0})$ & 0 \\
\hline $\begin{array}{l}\text { Intraventricular } \\
\text { hemorrhage }(\mathrm{n} / \mathbf{\%})\end{array}$ & $6(\mathbf{1 5 . 0})$ & $2(\mathbf{6 . 7})$ & 0 \\
\hline Cephalohematoma (n/\%) & $6(\mathbf{1 5 . 0})$ & $4(\mathbf{1 . 3})$ & $1(\mathbf{3 . 3})$ \\
\hline Pre-natal infection, $(\mathrm{n} / \mathbf{\%})$ & $3 \mathbf{( 7 , 5 )}$ & 0 & 0 \\
\hline
\end{tabular}

Note: $* *$ - significant differences between the prospective study groups using exact Fisher's test (two-sided test). Intraventricular hemorrhage (IVH) was also more common in children than from mothers who had manifested placental dysfunction, compared with a population of pre-nosological PD, RR 2.25, $95 \%$ CI [0.49-10.38], $\mathrm{p}=0.30$, although the results were also not statistically significant.

Cephalohematomas were detected in all study groups, the largest number of them, $6(15 \%)$, occurred in newborns whose mothers had fetal growth retardation syndrome but this indicator was not significantly higher than in the subgroup of pregnant women with prenatal PD, RR $1.125,95 \% \mathrm{CI}$ [0.35-3.64], $\mathrm{p}=0.84$, and the control group, RR 4.50, 95\% CI [0.57-35.43], $\mathrm{p}=0.15$.

We also noted that cases of intrauterine infection were observed only in infants born prematurely from women of clinical subgroup A, 3 (7.5\%). Only $6(15 \%)$ infants of clinical subgroup A needed transfer for further treatment to specialized neonatal hospitals.

Thus, the course of labor and the postpartum period in pregnant women with manifested placental dysfunction secondary to gestational endotheliopathy (FGR) was associated with an increase in cases of premature birth, RR 2.14, 95\% CI [1.04 - 4.40], $\mathrm{p}=0.04$, indications for abdominal operative delivery, RR 5.62, 95\% CI [1.39-22.75], $\mathrm{p}=0.015$, cases of acute fetal distress, RR 3.37, $95 \%$ CI [1.27-8.94], $\mathrm{p}=0.014$, lower infant weight $(\mathrm{p}<0.05)$, lower infant APGAR scores $(\mathrm{p}<0.05)$ at the $1^{\text {st }}$ and $5^{\text {th }}$ minutes. The incidence of adverse perinatal outcomes was higher among newborns whose mother was diagnosed with FGR secondary to endothelial dysfunction.

Conclusions. PD secondary to GE lead to premature birth, fetal distress, increases the percentage of caesarean section, contributes to the delay of fetal growth and weight of infants, unsatisfactory infant status and perinatal complications.

\section{REFERENCES}

1. Игнатко, И.В. Прогностические маркеры синдрома задержки роста плода / И.В. Игнатко, М.М. Мирющенко // Журнал научных статей «Здоровье и образование в XXI веке». - 2016. - Т.18, № 1. - С.1-4.

2. Коньков Д.Г. Патогенез та профілактика перинатальних втрат що обумовлені ендотеліальною дисфункцією: дис. ... доктора мед. наук: 14.01.01 / Д.Г. Коньков - Вінниця, 2015. - 361 с.

3. вчарук В.В. Клініко-патогенетичні аспекти діагностики та профілактики плацентарної дисфункції: дис. ... канд. мед. наук: 14.01.01 / В.В. Овчарук - Тернопіль, 2017. - 213 с.

4. Amato, N.A. Placental insufficiency and intrauterine growth retardation / N.A. Amato, G. Maruotti, G. Scillitani et al. // Minerva Ginecol. 2007. - Vol. 59, N 4.-P 357-367. 
5. Burton, G.J., Fowden, A.L., Thornburg, K.L. Placental origins of chronic disease. Physiol Rev. 2016;96:1509-1565.

6. Crocker I.P. Review: Endothelial progenitor cells in pregnancy and obstetric pathologies / I P. Crocker, P.I. Sipos // Placenta. - 2013. - Vol. 34, suppl. - P. S62-S67.

7. McCowan L.M., Figueras F., Anderson N.H. Evidence-based national guidelines for the management of suspected fetal growth restriction: comparison, consensus, and controversy. Am J Obstet Gynecol. 2018; 218(2S):S855-S868.

8. Rabinovich A, Tsemach T, Novack L, et al. Late preterm and early term: when to induce a growth restricted fetus? A population-based study. J Matern Fetal Neonatal Med 2017 Mar 22:1e7.

9. Veerbeek, J.H., Nikkels, P.G., Torrance, H.L. et al, Placental pathology in early intrauterine growth restriction associated with maternal hypertension. Placenta. 2014; 35:696-701.

10. Zhang, S., Regnault, T., Barker, P., Botting, K., McMillen, I., McMillan, C., et al. Placental adaptations in growth restriction. Nutrients. 2015. 7, 360-389. 